\title{
The Effect of LncRNA H19/miR-194- 5p Axis on the Epithelial-Mesenchymal Transition of Colorectal Adenocarcinoma
}

\author{
Chang-feng Li ${ }^{\mathrm{a}}$ Yong-chao Li ${ }^{\mathrm{b}}$ Yun Wang ${ }^{\mathrm{c}}$ Li-bo Sun ${ }^{\mathrm{b}}$ \\ aDepartment of Endoscopy Center, China-Japan Union Hospital of Jilin University, Changchun, \\ bDepartment of Gastrointestinal surgery, China-Japan Union Hospital of Jilin University, Changchun, \\ 'Department of Medicine, Liver and Biliary Disease Hospital of Jilin Province, Changchun, China
}

\section{Key Words}

Colorectal adenocarcinoma - LncRNA H19 • miR-194 • FoxM1 • Epithelial mesenchymal transition

\begin{abstract}
Background/Aims: Since the combined actions of IncRNAs and miRNAs have been considered to be involved in the occurrence and development of various neoplasms, the main purpose of this study was to discover whether and how IncRNA H19 and miR-194 influenced the epithelial-mesenchymal transition (EMT) process of colorectal adenocarcinoma (CRA). Methods: Totally 214 pairs of CRA and adjacent normal tissues were collected, and 5 human CRA cell lines (i.e. HCT116, HT-29, RKO SW280 and Lovo) were purchased. Quantitative reverse transcription-polymerase chain reaction (qRT-PCR) was adopted to quantify the $\mathrm{H} 19$ and miR-194-5p expressions in cells and tissues. The expressions of FoxM1, E-cadherin, vimentin, $\mathrm{N}$-cadherin were determined using western blot. On the side, si-H19, si-NC, miR-194-5p mimic, miR-194-5p inhibitor and negative control (NC) were transfected into CRA cell lines. Meanwhile, the invasive, migratory and proliferative conditions of the cells were assessed through transwell, wound healing and colony-forming experiments, with final verification of the relationship between $\mathrm{H} 19$ and miR-194-5p employing dual-luciferase reporter gene assay. Results: Highly-expressed H19, lowly-expressed miR-194-5p, low-grade differentiation and lymph node metastasis appeared as the independent predictors of unfavorable prognosis in CRA patients' (all $P<0.05$ ). It indicated that FoxM1 expression displayed positive correlations with $\mathrm{H} 19$ expression, yet negative associations with miR-194-5p expression within CRA tissues $(P<0.05)$. In addition, transfection of H19-siRNA and miR-145-5p mimic triggered a conspicuous increase in E-cadherin expression, as well as an evidently down-regulation in vimentin and $\mathrm{N}$-cadherin expressions within HT29 and RKO cells $(P<0.05)$. On the other hand, the invasive and migratory capacities of CRA cells were significantly hindered $(P<0.05)$. Moreover, the luciferase reporter gene assay confirmed that $\mathrm{H} 19$ modified miR-194-5p expression through directly targeting at it $(P<0.05)$. Ultimately, FoxM1 could reverse the role




\section{Cellular Physiology Cell Physiol Biochem 2018;50:196-213

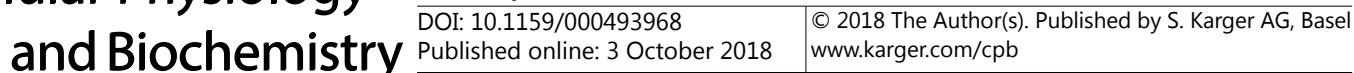 \\ Li et al.: IncRNA H19/miR-194-5p/FoxM1 Signaling and Colorectal Adenocarcinoma}

of miR-194-5p in inhibiting invasion, migration and EMT of CRA cells $(P<0.05)$. Conclusion: LncRNA H19/miR-194/FoxM1 axis could serve as a profound target for the diagnosis and treatment of CRA.

(C) 2018 The Author(s)

Published by S. Karger AG, Basel

\section{Introduction}

Colorectal cancer (CRC) is a globally-observed malignancy that causes up to as high as 0.6 million new deaths per year [1]. The 5-year overall survival (OS) rate of early-stage CRC patients is greater than $90 \%$, while the advanced CRC patients possess a rather low 5 -year OS rate at merely $10 \%$ [1]. Currently plenty of CRC patients, especially those with colorectal adenocarcinoma (CRA), are identified until the late phase of the disorders, thus the sufferers' prognosis is quite unsatisfactory, and seeking valid diagnostic and treatment schemes for early-stage CRC or CRA becomes extremely critical [2]. Of note, epithelial-mesenchymal transition (EMT) plays a vital role underlying the pathogenesis of CRA, which is embodied in its interfering cell-cell adherence and facilitating tumor metastasis [3-9].

Non-coding RNAs (ncRNAs), mainly divided into long non-coding RNAs (lncRNAs) and microRNAs (miRNAs), counted for much in regulating tumorigenesis [10-12]. For example, over-expressed IncRNA MX1-1 was associated with reduced recurrence-free survival rate of prostate cancer patients [13]. Furthermore, IncRNA H19 could modify progression and EMT of tumor cells (e.g. CRC), and it was located close to the telomeric region of chromosome $11 \mathrm{p} 15.5$, where multiple cancer-associated genes were harbored [14-18].

More than that, H19 could modulate EMT-related genes by sponging miRNAs [19]. To be specific, $\mathrm{H} 19$ was able to alter proliferation of gallbladder cancer cells via inhibiting miR194-5p and thereby modulating AKT2 expression [20]. In addition, miR-194 interacting with FoxM1 not only regulated metastasis of CRC cells, but also mediated EMT of nonsmall cell lung cancer cells [21-23]. However, scholars' opinions were divided regarding the contribution of miR-194 to tumor development. To be specific, miR-194 was documented to inhibit EMT process of endometrial cancer cells via suppressing BMI-1 [24], whereas another investigation asserted that miR-194 promoted EMT within CRC [25]. Therefore, how on earth H19 and miR-194 influenced EMT of CRA remained unclear.

In response, this investigation was aimed to investigate the function of lncRNA H19/ miR-194-5p axis underlying the EMT process of CRA, which might assist in developing novel strategies for upgrading the prognostic status of CRA patients.

\section{Materials and Methods}

Collection of CRA tissues and culture of CRA cells

From Jan 2016 to Oct 2017, altogether 214 CRA tissues and corresponding para-carcinoma tissues were collected from Hospital of Jilin Province. The patients hardly received surgery or chemotherapy before, and they were confirmed with CRA by pathological examinations. The CRA subjects would be excluded if they: 1) were with recurrent CRA; 2) had histories of other tumors, genetic diseases and disorders relevant to heart, kidney, liver, endocrine system and central nervous system; 3) were genetically related to each other; and 4) did not offer detailed personal information and clinical data. Furthermore, human CRA cell lines (i.e. HCT116, HT-29, RKO, SW280 and Lovo) and regular colonic epithelial cell line (i.e. CCD-18Co) were purchased from American Standard Biology Collection (ATCC). The CRA cell lines were classified based on Duke grading [26]. They were cultured within DMEM medium (Gibco) or RPMI 1640 medium (Gibco) in 5\% $\mathrm{CO}_{2}$ at $37^{\circ} \mathrm{C}$. The medium was added with $10 \%$ fetal bovine serum (FBS), $100 \mathrm{U} / \mathrm{ml}$ penicillin and $100 \mu \mathrm{g} /$ $\mathrm{ml}$ streptomycin. When cells achieved the logarithmic growth phase, they were digested with $0.25 \%$ trypsin and were filtrated into the single-cell suspension.

Cell transfection

Genepharma Inc. (China) synthesized the targeted siRNA for IncRNAH19 (i.e. si-H19) and siNC. The sequences of si-H19-1 and si-H19-2 were, respectively, 5'-CCAACAUCAAAGACACCAUdTdT-3' and 5'-UAAGUCAUUUGCACUGGUUdTdT-3'. The full-length H19 cDNA was sub-cloned into a pCDNA3.1 


\section{Cellular Physiology Cell Physiol Biochem 2018;50:196-213 \begin{tabular}{l|l} 
and Biochemistry & $\begin{array}{l}\text { DOI: 10.1159/000493968 } \\
\text { Published } 2018 \text { The Author(s). Published by S. Karger AG, Basel }\end{array}$ \\
www.karger.com/cpb
\end{tabular}

vector (Gene Pharma, China) to construct pCDNA3.1-H19 plasmid. Also, miR-194$5 p$ mimics, miR-194-5p inhibitor, negative control (NC) were all purchased from Qiagen (CA). They were transfected into cells using Lipofectamine ${ }^{\circledR} 2000$ (Invitrogen) when the cell confluency reached 90\%-95\%.

Quantitative reverse transcriptionpolymerase chain reaction ( $q R T-P C R$ )

Total RNA was extracted utilizing TRIzol (Ambion), and its concentration was measured with NanoDrop 2000 spectrophotometer (Thermo). After reverse transcription (RT), cDNAs were synthesized with assistance of first-strand cDNA synthesis kit (Biomiga). Then PCR was carried out based on the primers (Biotech Bioengineering, China) shown in Table 1, and GAPDH or U6 was set as the internal reference. The PCR reaction system $(20 \mu \mathrm{l})$ mainly incorporated cDNA(1 $\mu \mathrm{l}), 2 \times$ Master Mix $(10 \mu \mathrm{l})$ and $\mathrm{ddH}_{2} \mathrm{O}(7 \mu \mathrm{l})$. And the PCR reaction conditions were displayed as: 1) pre-denaturation at $94{ }^{\circ} \mathrm{C}$ for $2 \mathrm{~min}$; 2) 35 cycles of $94{ }^{\circ} \mathrm{C}$ for $30 \mathrm{~s}, 60^{\circ} \mathrm{C}$ for $30 \mathrm{~s}$ and $72^{\circ} \mathrm{C}$ for $30 \mathrm{~s}$; and 3) extension at $72{ }^{\circ} \mathrm{C}$ for $5 \mathrm{~min}$. Subsequently, $5 \mu \mathrm{g}$ PCR endproducts were handled with $1 \%$ agarose gel electrophoresis. Finally, we utilized ChemiDoc XRS gel imaging system of the Bio-Rad company (USA) to conduct grey scanning, and applied Quantity one-4.6.2 system for analyzing the results.

\section{CCK-8 experiment}

The cells were inoculated into 96-well plates at the density of 2000 /well after digestion and centrifugation. The initial time when cells attached to the wall was set as $0 \mathrm{~h}$, and CCK-8 kit (KaygenBiotech, China) was employed to examine the optical density (OD) values at the time points of $0 \mathrm{~h}, 24 \mathrm{~h}, 48 \mathrm{~h}$ and 72 h.

\section{Colony formation assay}

After culturing the cells for 1-2 weeks, pure methanol was added to fix cells for 15 min, and crystal violet was supplemented to dye cells for $20 \mathrm{~min}$. Then we washed the staining solution away, and the Petri plates were observed under the microscope. A segment was labeled on the plate, and it was set as the scale. At last, we counted the cell colonies whose diameter was $\geqslant$ scale size.

\section{Transwell experiment}

Matrigels (BD, USA) were diluted at the ratio of 1: 5 and were then spread evenly within the upper chamber (Corning, China) at $37{ }^{\circ} \mathrm{C}$ for $30 \mathrm{~min}$. About $8 \times 10^{4}$ cells were digested, centrifuged and counted. They were added to the upper chamber, and $200 \mu \mathrm{l} \mathrm{FBS-free} \mathrm{RPMI-1640} \mathrm{medium} \mathrm{(HyClone,} \mathrm{USA)} \mathrm{was} \mathrm{also}$ supplemented. Extra $600 \mu \mathrm{l}$ RPMI-1640 medium was added to the lower chamber. After 24-hour cultivation, cells were fixed with methanol/acetic acid (v/v: 3:1) for $15 \mathrm{~min}$, and were then stained with Giemsa for $10 \mathrm{~min}$. The inverted microscope was utilized to count cells within 5 views, and the average value of the counted cells was considered as the number of invasive cells. Besides, the migratory ability of cells was evaluated nearly in the same way as measuring the invasive ability, except that Matrigel was not layered.

\section{Scratch experiment}

The transfected cells were seeded in 6 -well plates at the density of $8 \times 10^{4}$. A sterile tip was employed to draw lines in the hole, and hardly any cells grew within the crossed places. We utilized a microscope to observe the widths between the scribed cells, and cell migration ability was determined according to the following formula: healing degree $=$

$$
\left(1-\frac{\text { scratch width at some certain point }}{\text { original scratch width }}\right) \times 100 \%
$$

\section{Western Blotting}

We applied RIPA lysate for extraction of total protein, whose concentration was measured with Anthos 2010 microplate reader. Then we adjusted the protein loading volume to $120 \mu \mathrm{g} / \mathrm{well}$, according to the result of protein concentration. The sodium dodecyl sulfate -polyacrylamide gel electrophoresis (SDS-PAGE) was carried out under $100 \mathrm{~V}$ for 2 hours, and films were transferred under $300 \mathrm{~mA}$ for 1 hour. Next, the PVDF membranes were fetched before the required bands were sealed with 5\% BSA at room 


\section{Cellular Physiology Cell Physiol Biochem 2018;50:196-213

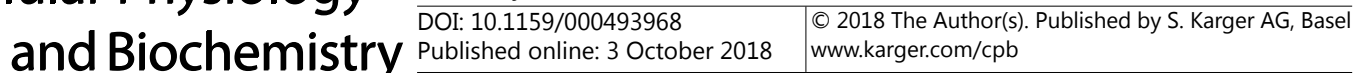 \\ Li et al.: IncRNA H19/miR-194-5p/FoxM1 Signaling and Colorectal Adenocarcinoma}

temperature for 2 hours. Subsequently, primary antibodies for E-cadherin (mouse anti-human, 1: 500, Santa Cruz Biotechnology, USA), N-cadherin (mouse anti-human, 1: 300, Santa Cruz Biotechnology, USA), vimentin (mouse anti-human, 1: 300, Santa Cruz Biotechnology, USA) and $\beta$-actin (mouse anti-human, 1 : 300, Santa Cruz Biotechnology, USA) were mixed with the cultured cells at $4{ }^{\circ} \mathrm{C}$ for overnight. On top of that, we added goat anti-mouse/goat anti-rabbit secondary antibodies (1: 2000) that were labeled with horseradish peroxidase (HRP). The samples' membrane surfaces were coated in a dark room, according to the instructions of chemiluminescent kit (Beyotime, China). Finally, films were exposed to X-ray, and the protein bands were developed, fixed, scanned and quantified using Quality One 4.5 software.

\section{Double luciferase reporter gene assay}

We took the advantage of PCR to amplify H19 cDNA fragments that included specific miR-194-5p binding sites, and then cloned them into the luciferase reporter vector (i.e. psiCHECK2) to produce H19 Wt. Through a similar way, H19 Mut that contained mutant sequences at the miR-194-5p binding site was constructed. Subsequently, miR-194-5p mimic and miR-NC were, respectively, transfected into HT29 and RKO cells that have been transfected with H19 Wt, H19 Mut and psiCHECK2. After 48-h transfection, we added $100 \mu \mathrm{l}$ PLB buffer to each well and collected $20 \mu \mathrm{l}$ cell lysates after 15-min shake at room temperature. The cell lysates were then applied to the luminous panel, and the background values were scanned for 2 seconds with GloMax bioluminescence detector. The experimental values were also scanned for 2 seconds after addition of $100 \mu \mathrm{l}$ LAR II solution to each sample. Finally, we added $100 \mu$ l Stop\&Glo® Reagent into each sample, and examined the results with the luminescent detector.

\section{Statistical analyses}

The whole statistical analyses were performed via SPSS 17.0 statistical software. The measurement data were expressed as mean \pm standard deviation (SD), and the enumeration data were presented as percentage (\%). The multi-group comparisons were processed with one-way analysis of variance (ANOVA), and inter-group comparisons were managed with Bonferroni method. A $P$ values less than 0.50 was deemed as statistically significant.

\section{Results}

\section{H19 and miR-194-5p expressions within CRA tissues and cells}

According to the TCGA Data Portal of starBASE v2.0, we found that H19 expressions were significantly distinct between cancer tissues and normal tissues $(P<0.05)$ (Fig. 1A), and $\mathrm{H} 19$ expression within CRC tissues was remarkably beyond that within adjacent normal tissues $(P<0.05)$ (Fig. 1B). Also a negative correlation between H19 expression and miR-194$5 p$ expression was found among the 299 CRC samples $(P<0.05)$ (Fig. 1C). Analogously, it was drawn from the tissues we collected that H19 expression within CRA tissues was sharply elevated, yet miR-194-5p expression was substantially decreased in comparison to adjacent normal tissues $(P<0.05)$ (Fig. 2A). What's more, H19 expression within four CRA cell lines (i.e. HCT116, HT29, RKO, SW480 and Lovo) exceeded that within normal colonic epithelial cell line (i.e. CCD-18Co) $(P<0.05)$, whereas miR-194-5p expression within HCT116, HT29, RKO, SW480 and Lovo were significantly lower than that within CCD-18Co $(P<0.05)$ (Fig. 2B). H19 and miR-194-5p expressions were also negatively inter-related within the gathered CRA tissues $(P<0.05)$ (Fig. 2C).

Correlation between IncRNA H19 or miR-194-5p expression and overall survival (OS) of CRA patients

According to the expression performance of IncRNA H19 and miR-194-5p, the obtained CRA tissues were categorized into highly-expressed H19 group (> median H19 expression) and lowly-expressed H19 group ( $\leqslant$ median H19 expression). The identical population was also divided into highly-expressed miR-194-5p group ( $>$ median miR-194-5p expression) and lowly-expressed miR-194-5p group ( $\leqslant$ median miR-194-5p expression). The results indicated that $\mathrm{H} 19$ and miR-194-5p expressions were both markedly correlated with family 

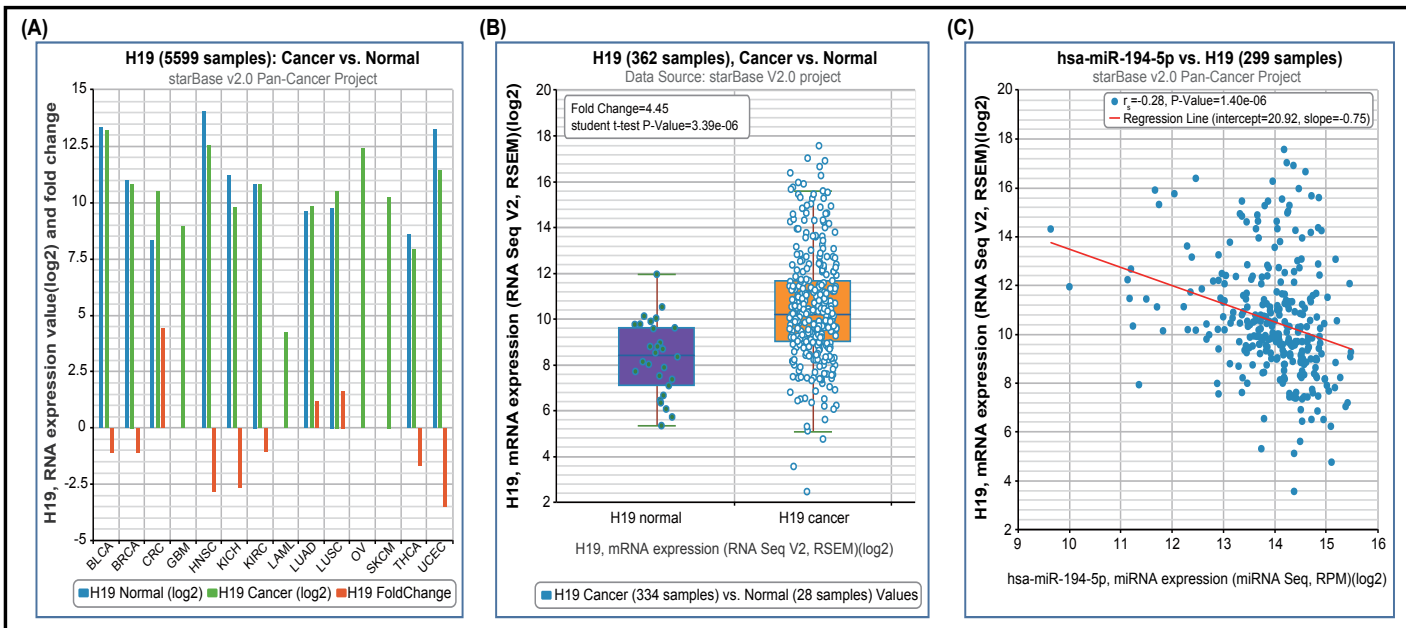

Fig. 1. LncRNA H19 and miR-194-5p expressions within colorectal adenocarcinoma(CRA) tissues and cells. (A) H19 expressions were compared between cancer tissues and normal tissues according to the TCGA Data Portal of starBASE v2.0. (B) H19 expression was compared between CRA tissues and normal tissues in light of the TCGA Data Portal of starBASE v2.0. (C) H19 expression was negatively correlated with miR-194-5p expression within CRA in line with the TCGA Data Portal of starBASE v2.0.

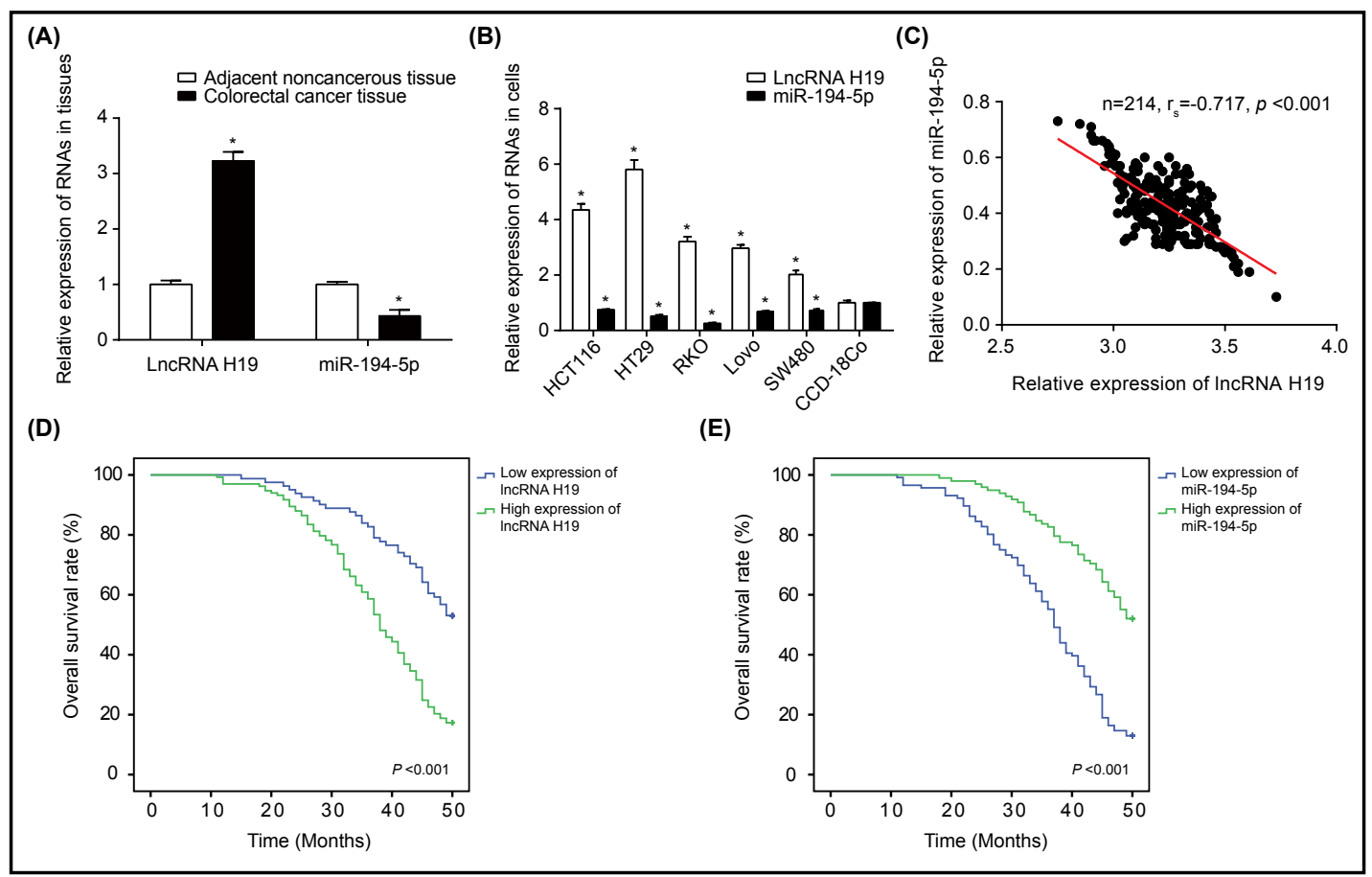

Fig. 2. (A) H19 and miR-194-5p expressions were compared between CRA tissues and adjacent normal tissues. *: P< 0.05 when compared with adjacent normal tissues. (B) H19 and miR-194-5p expressions were compared between CRA cell lines (i.e. HCT116, HT29, RKO and Lovo) and normal colonic epithelial cell line (i.e. CCD-18Co). *: P< 0.05 when compared with CCD-18Co. (C) A negative correlation between H19 expression and miR-194-5p expression was observed among the included CRA subjects. (D) The lowly-expressed H19 was associated with higher overall survival (OS) rate of CRA patients. (E) The highlyexpressed miR-194-5p was found to be with more desirable OS rate. 


\section{Cellular Physiology Cell Physiol Biochem 2018;50:196-213 \begin{tabular}{l|l} 
DOI: 10.1159/000493968 & a 2018 The Author(s). Published by S. Karger AG, Basel \\
www.karger.com/cpb
\end{tabular}

history, differentiation degree, serum CEA content, AJCC stage and metastatic stage of CRA patients $(P<0.05)$ (Table 2). However, neither H19 expression nor miR-194-5p expression showed any significant correlation with age, sex or tumor location $(P>0.05)$. In addition, single-factor regression analysis claimed that higher $\mathrm{H} 19$ expression, lower miR-194-5p expression, lower differentiation grade, preoperative high serum CEA content, $\mathrm{AJCC}_{\mathrm{III+IV}}$ stage and metastatic conditions (i.e. $\mathrm{M}_{1 \mathrm{a}}$ and $\mathrm{M}_{1 \mathrm{~b}}$ ) were significantly associated with poor prognosis of CRA patients $(P<0.05)$ (Table $3)$. The results of multivariate regression analysis pointed out that merely higher H19 expression, lower miR-194$5 p$ expression, lower grade of differentiation, late AJCC stage, lymph node metastasis and distal metastasis served as the independent determinants for poor prognosis of CRA patients $(P<0.05)$. Simultaneously, the survival status of patients with lower H19 expression or higher miR-194-5p expression appeared to be much more desirable than ones with higher H19 expression or lower miR194-5p expression $(P<0.05)$ (Fig. 2D and 2E).

Comparison of proliferation, EMT and viability among SW480 (i.e. without metastasis), HT-29 (i.e. with LN metastasis) and HCT-116 (i.e. with distant metastasis) cell lines

It was drawn from Fig. 3A that the distantly metastatic tissues displayed the maximum correlation coefficient (i.e. $r_{s}$ ) between $\mathrm{H} 19$ expression and miR-194-5p expression $\left(\mathrm{r}_{\mathrm{s}}=\right.$

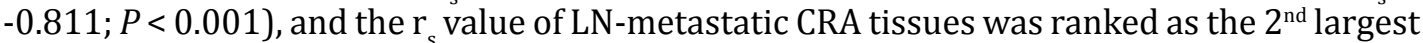
$\left(r_{\mathrm{s}}=-0.684 ; P<0.001\right)$. Besides, HCT-116 cell line showed the most pronounced proliferative ability and viability, whereas SW280 cell line was associated with the least proliferation and viability (all $P<0.05$ ) (Fig. 3B and 3C). At the meantime, HCT-116 cell line was determined with the lowest E-cadherin expression, as well as the highest expressions of $\mathrm{N}$-cadherin and vimentin $(P<0.05)$ (Fig. 3D).

\section{H19 and miR-194-5p regulated EMT, invasion and migration of CRA cells}

H19 expression and miR-194-5p expression were, respectively, largely depressed within si-H19 group and miR-194-5p inhibitor group, when compared with NC group $(P<0.05)$ (Fig. 4A). In contrast, H19 and miR-194-5p expressions were, separately, greatly promoted when CRA cells were treated with pcDNA3.1-H19 and miR-194-5p mimic $(P<0.05)$. Furthermore, si-H19 and miR-145-5p mimic groups possessed significantly up-regulated E-cadherin expression, as well as down-regulated vimentin and $\mathrm{N}$-cadherin expressions $(P<0.05)$. The pcDNA3.1-H19 and miR-194-5p inhibitor groups were reflected with an opposite trend regarding the above protein expressions $(P<0.05)$ (Fig. 4B and $4 \mathrm{C})$. More than that, less 
Table 3. The relationship between clinical characteristics and the colorectal cancer patients' overall survival

\begin{tabular}{|c|c|c|c|c|c|c|}
\hline \multirow{2}{*}{ Characteristics } & \multicolumn{3}{|c|}{ Univariate analysis } & \multicolumn{3}{|c|}{ Multivariate analysis } \\
\hline & Hazard Ratio & $95 \% \mathrm{CI}$ & $P$ value & Hazard Ratio & $95 \% \mathrm{CI}$ & P value \\
\hline \multicolumn{7}{|l|}{ LncRNAH19 expression } \\
\hline High vs. Low & 2.78 & $1.91-4.03$ & $<0.001$ & 3.968 & $2.58-6.10$ & $<0.001$ \\
\hline \multicolumn{7}{|l|}{ miR-194-5p expression } \\
\hline High vs. Low & 0.315 & $0.22-0.45$ & $<0.001$ & 0.232 & $0.16-0.35$ & $<0.001$ \\
\hline \multicolumn{7}{|l|}{ Sex } \\
\hline Female vs. Male & 1.23 & $0.89-1.69$ & 0.215 & 0.986 & $0.70-1.39$ & 0.934 \\
\hline \multicolumn{7}{|l|}{ Age } \\
\hline$>50$ vs. $\leq 50$ & 0.92 & $0.66-1.28$ & 0.615 & 0.91 & $0.65-1.28$ & 0.585 \\
\hline \multicolumn{7}{|l|}{ Family history } \\
\hline Negative vs. Positive & 0.853 & $0.61-1.19$ & 0.353 & 1.238 & $0.86-1.78$ & 0.244 \\
\hline \multicolumn{7}{|l|}{ Tumor Location } \\
\hline Rectum vs.Colon & 1.536 & $1.11-2.12$ & 0.009 & 1.371 & $0.98-1.91$ & 0.063 \\
\hline \multicolumn{7}{|l|}{ Differentiation } \\
\hline \multirow{2}{*}{\multicolumn{7}{|c|}{ Preoperative serum CEA (ng/mL) }} \\
\hline & & & & & & \\
\hline$>6$ vs. $\leq 6$ & 1.785 & $1.27-2.51$ & 0.001 & 1.367 & $0.93-2.00$ & 0.108 \\
\hline \multicolumn{7}{|l|}{ AJCC stage } \\
\hline III vs. I + II & 0.15 & $0.06-0.37$ & $<0.001$ & 0.21 & $0.06-0.72$ & 0.013 \\
\hline IV vs. I+II & 0.07 & $0.03-0.15$ & $<0.001$ & 0.17 & $0.05-0.62$ & 0.007 \\
\hline \multicolumn{7}{|l|}{ Metastasis } \\
\hline M 1 a vs. M0 & 0.18 & $0.09-0.37$ & $<0.001$ & 0.22 & $0.08-0.60$ & 0.003 \\
\hline Distant metastasis vs. Negative & 0.03 & $0.01-0.19$ & $<0.001$ & 0.1 & 0.01-0.99 & 0.049 \\
\hline
\end{tabular}

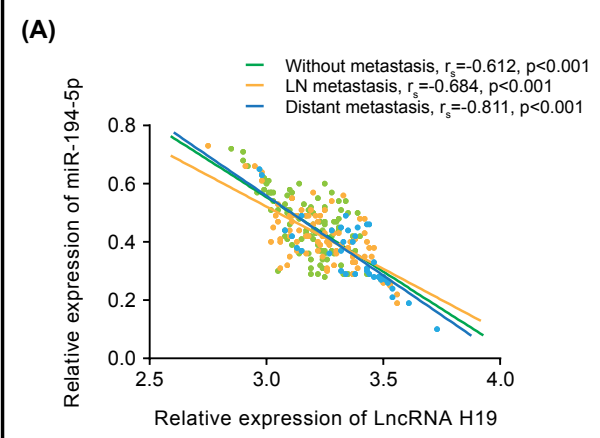

(B)

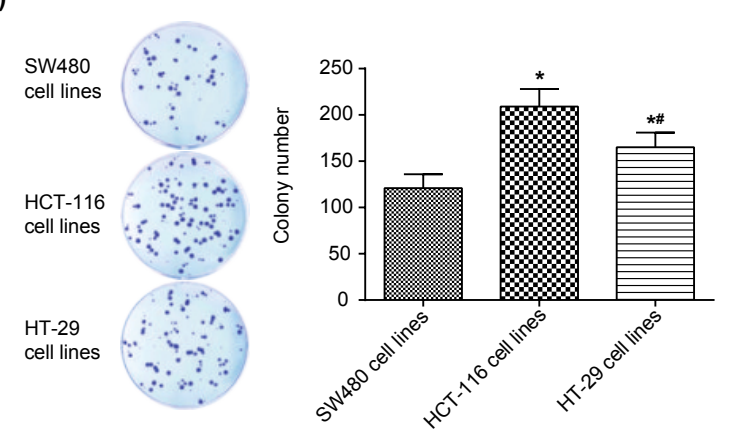

(C)

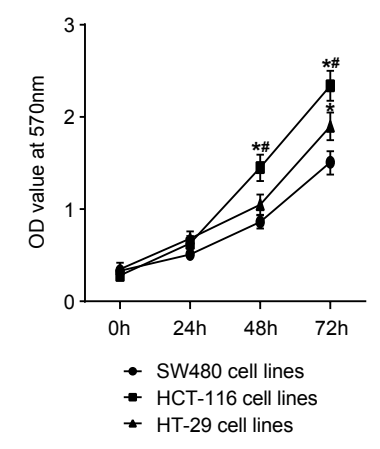

(D)
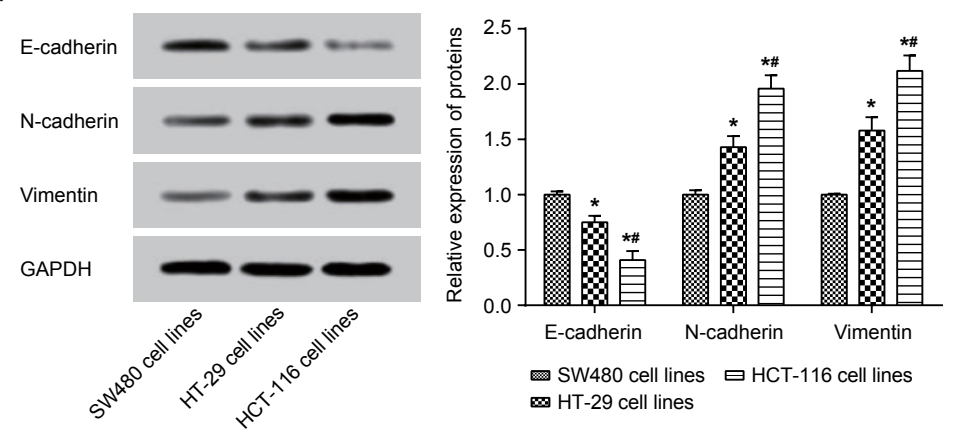

Fig. 3. The correlation between H19 and miR-194-5p (A) were determined within SW480, HCT-116 and HT29 cell lines, and the cell lines' proliferation (B), viability (C) and epithelial-mesenchymal transition (EMT)specific proteins (i.e. E-cadherin, N-cadherin and vimentin) (D) were also compared. 


\section{Cellular Physiology \begin{tabular}{ll|l} 
and Biochemistry Published online: 3 October 2018 & $\begin{array}{l}\text { DO } 2018 \text { The Author(s). Published by S. Karger AG, Basel } \\
\text { www.karger.com/cpb }\end{array}$
\end{tabular}}

Li et al.: IncRNA H19/miR-194-5p/FoxM1 Signaling and Colorectal Adenocarcinoma

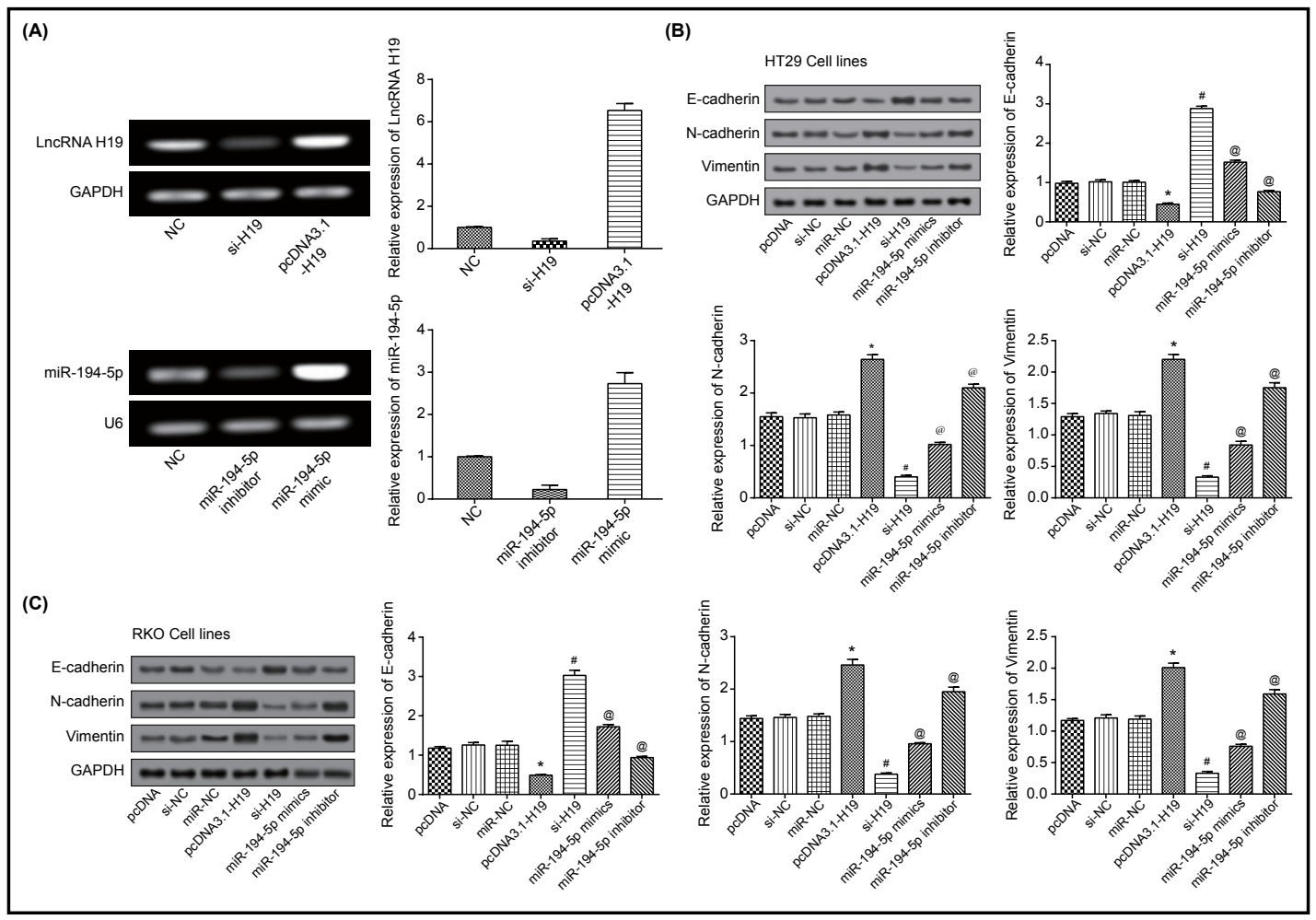

Fig. 4. Effects of H19 and miR-194-5p on EMT process of colorectal adenocarcinoma (CRA) cells. (A) H19 expression was detected after transfection with si-H19 and pcDNA3.1-H19, and miR-194-5p expression was detected after transfection with miR-194-5p mimic and miR-194-5pinhibitor. (B) The expressions of endothelial-mesenchymal transition (EMT)-related proteins (i.e. E-cadherin, N-cadherin and Vimentin) were determined among pcDNA3.1 H19, si-H19, miR-194-5p mimics and miR-194-5p inhibitor groups within HT29 (B) and RKO (C) cell lines. *: P< 0.05 when compared with pcDNA; \#: P< 0.05 when compared with si-NC; ${ }^{@}: \mathrm{P}<0.05$ when compared with miR-NC.

trans-membrane cells were observed within si-H19 and miR-194-5p mimic groups $(P<$ 0.05), and addition of pcDNA3.1-H19 or miR-194-5p inhibitor, to a great extent, facilitated the cells to cross membranes $(P<0.05)$ (Fig. 5). Similarly, the results of scratch assays and CCK-8 experiments presented that si-H19 and miR-194-5p mimic groups were associated with conspicuously restrained cell motility $(P<0.05)$ (Fig. 6). On the contrary, treatments with pcDNA3.1-H19 and miR-194-5p inhibitor accelerated cell motility $(P<0.05)$.

\section{H19 targeted miR-194-5p to inhibit its expression}

We predicted the targeting sites between $\mathrm{H} 19$ and miR-194-5p via Starbase 2.0 software (http://starbase.sysu.edu.cn/seedTargetInfo.php?type=lncRNA\&database=hg19\&name =hsa-miR-194-5p\&geneName=H19\&autoId=1100\&orgTable=mirLncRNAInteractionsA II) (Fig. 7A). Furthermore, consistent with the prediction results, the luciferase activity of H19 Wt+miR-194-5p mimics group was manifested to be weaker than that of control group $(P<0.05)$, nonetheless, the luciferase activity of H19 Mut+miR-194-5p mimics group and psiCHECK2 group failed to show any differences from that of H19 Wt+miR-NC group (Fig. 7B). Besides, lowly-expressed H19 greatly increased miR-194-5p expression $(P<0.05)$, while regulated miR-194-5p expressions were unable to alter the expression of $\mathrm{H} 19(P<0.05)$ (Fig. 7C and 7D). 


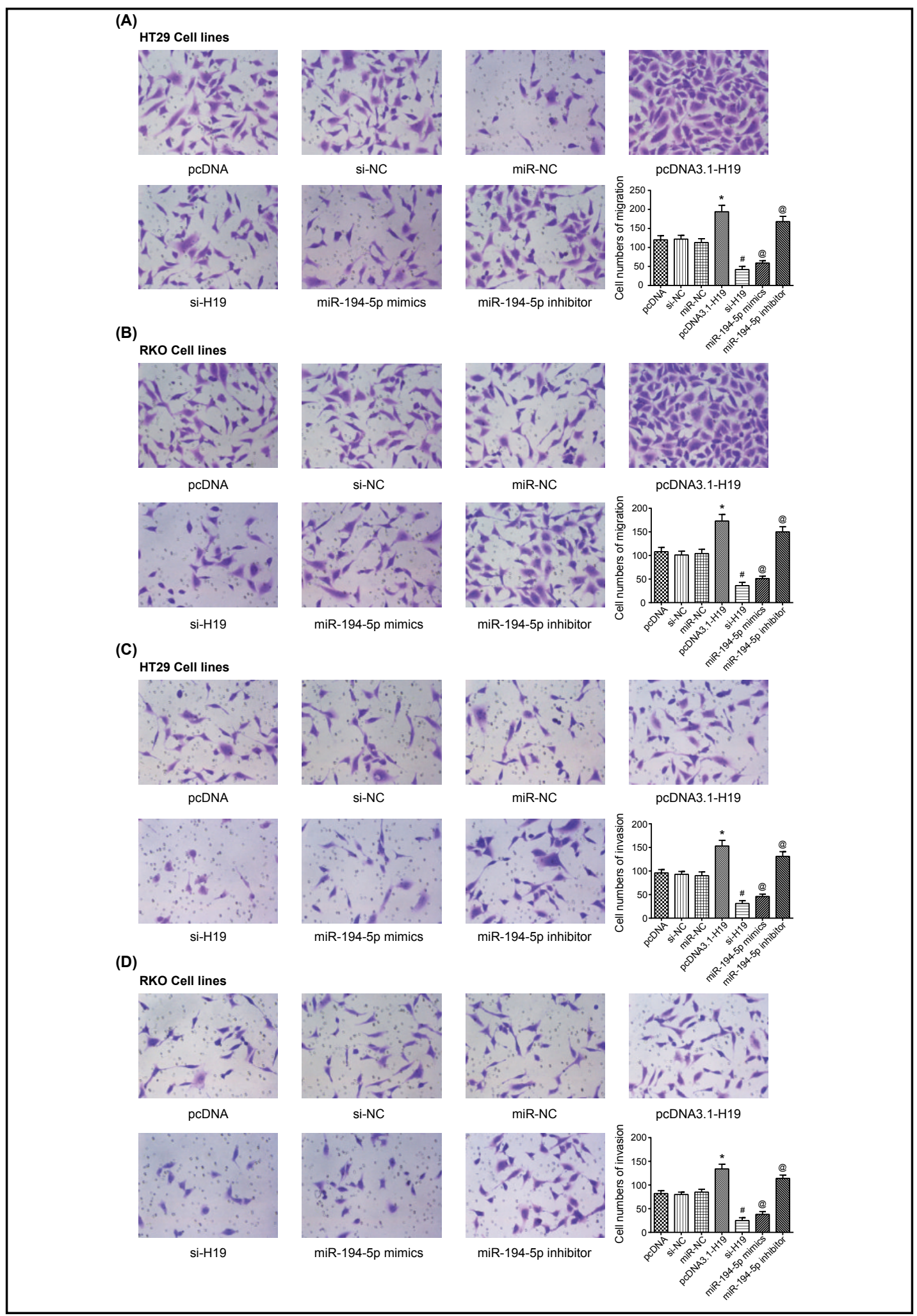

Fig. 5. The migratory (A-B) and invasive (C-D) abilities of colorectal adenocarcinoma (CRA) cells were observed by Transwell assay among pcDNA3.1 H19, si-H19, miR-194-5p mimics and miR-194-5p inhibitor groups within HT29 and RKO cell lines. *: P< 0.05 when compared with pcDNA; *: P< 0.05 when compared with si-NC; ${ }^{\circledR}: \mathrm{P}<0.05$ when compared with miR-NC.

\section{KARGER}


Cellular Physiology

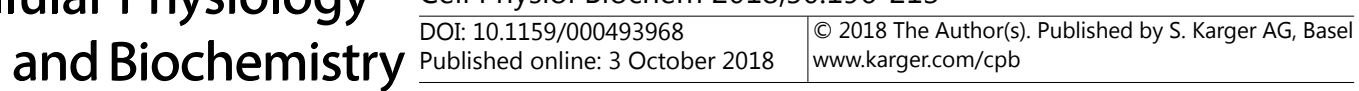

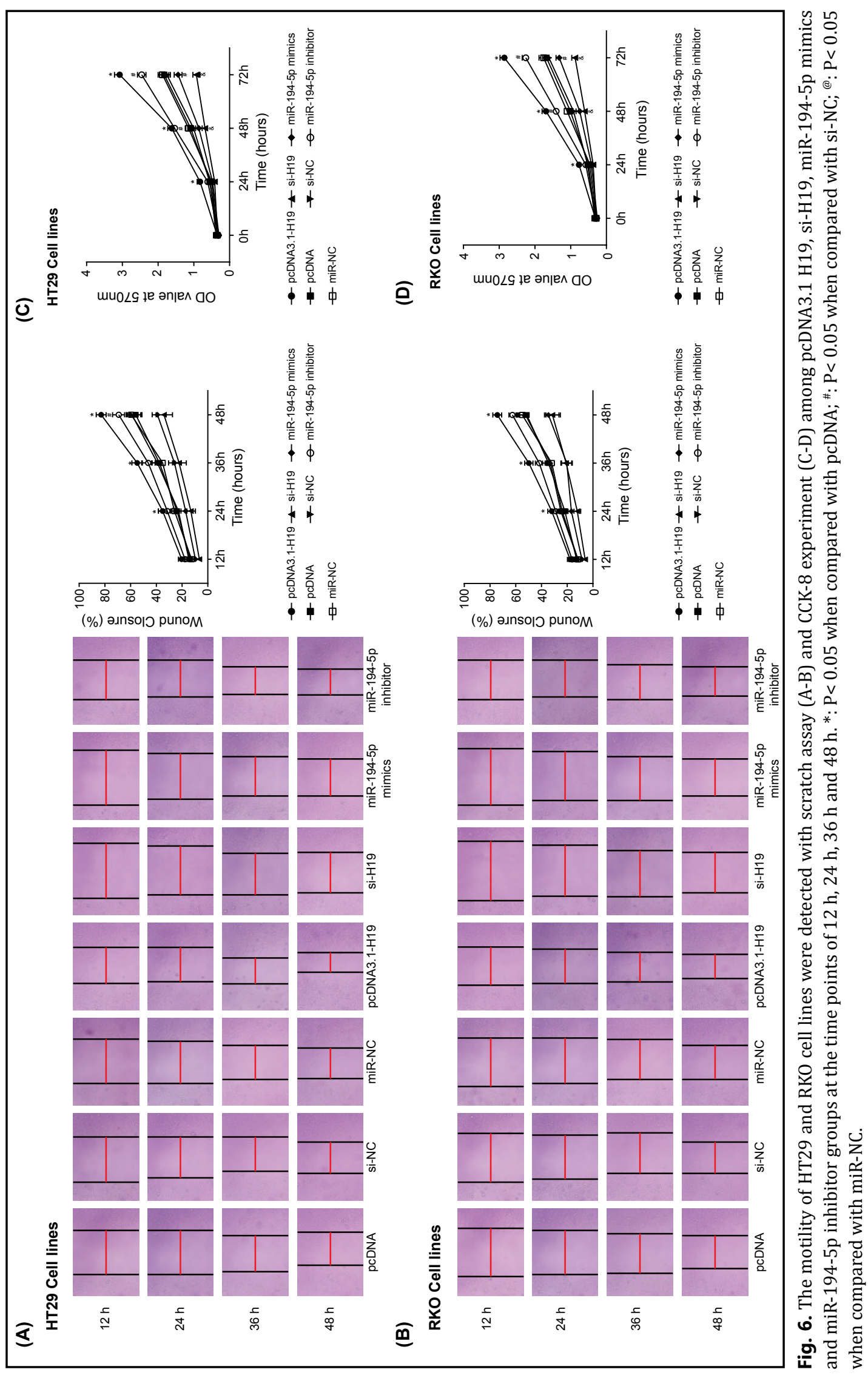




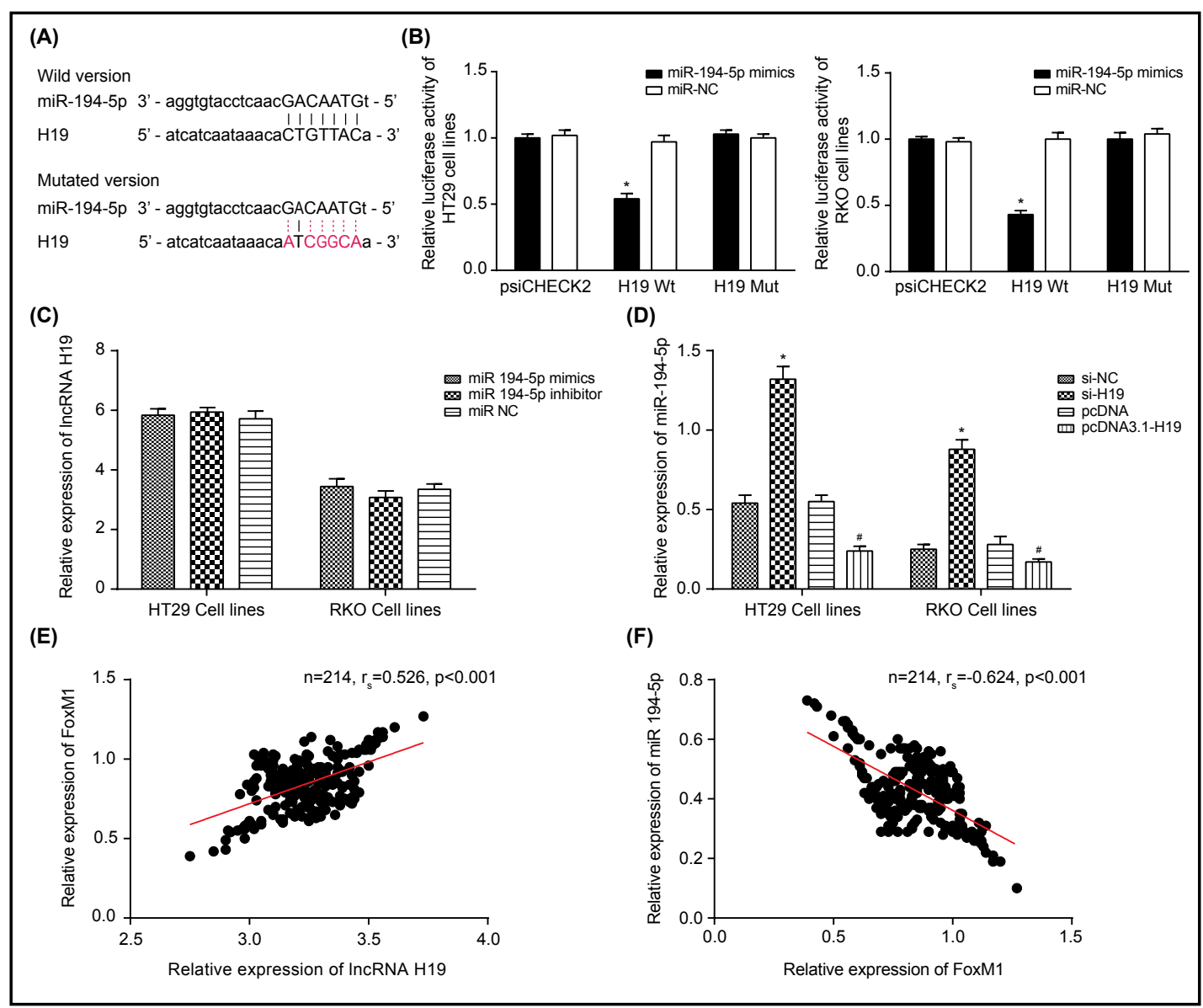

Fig. 7. The relationships among lncRNA H19, miR-194-5p and FoxM1. (A) H19 targeted miR-194-5p in specific sites. (B) The luciferase activities of H19 Wt+miR-194-5p mimic and H19 Mut+miR-194-5p mimic groups were evaluated within HT29 and RKO cell lines.*: P< 0.05 when compared with miR-NC. (C) The effects of miR-194-5p mimic and miR-194-5p inhibitor on H19 expression were assessed within HT29 and RKO cell lines. (D) The effects of down- and up-regulated H19 on miR-194-5p expression were appraised within HT29 and RKO cell lines. *: P< 0.05 when compared with si-NC; \#: P< 0.05 when compared with pcDNA. (E) The H19 expressions were positively correlated with FoxM1 expressions within included CRA tissues. (F) The miR-194-5p expressions were negatively correlated with FoxM1 expressions within included CRA tissues.

\section{H19 and miR-194-5p modified EMT, invasion and migration of CRA cells through acting on downstream FoxM1}

It was clinically indicated that FoxM1 expression was positively correlated with H19 expression, yet negatively correlated with miR-194-5p expression within CRA tissues $(P<0.05)$ (Fig. 7E and 7F). Besides, FoxM1 expression was significantly decreased after transfection of si-H19 and miR-194-5p mimics $(P<0.05)$ (Fig. 8A and $8 B$ ). The result above indicated that the performance of FoxM1 was controlled and adjusted by H19 and miR-194$5 p$. We also observed that miR-194-5p+FoxM1 group displayed over-expressed vimentin and $\mathrm{N}$-cadherin, along with down-expressed E-cadherin, when compared with miR-194-5p group $(P<0.05)$ (Fig. 8C and 8D). It was insinuated that FoxM1 could reverse the reduced EMT process caused by miR-194-5p within CRA cells. In addition, the number of transmembrane cells within miR-194-5p+FoxM1 group far surpassed that within miR-194-5p group $(P<0.05)$ (Fig. 9), highlighting the role of FoxM1 in promoting miR-194-5p-suppressed migration and invasion of CRA cells. Analogously, the cell motility of miR-194-5p+FoxM1 group was encouraged in comparison to miR-194-5p group $(P<0.05)$ (Fig. 10).

\section{KARGER}




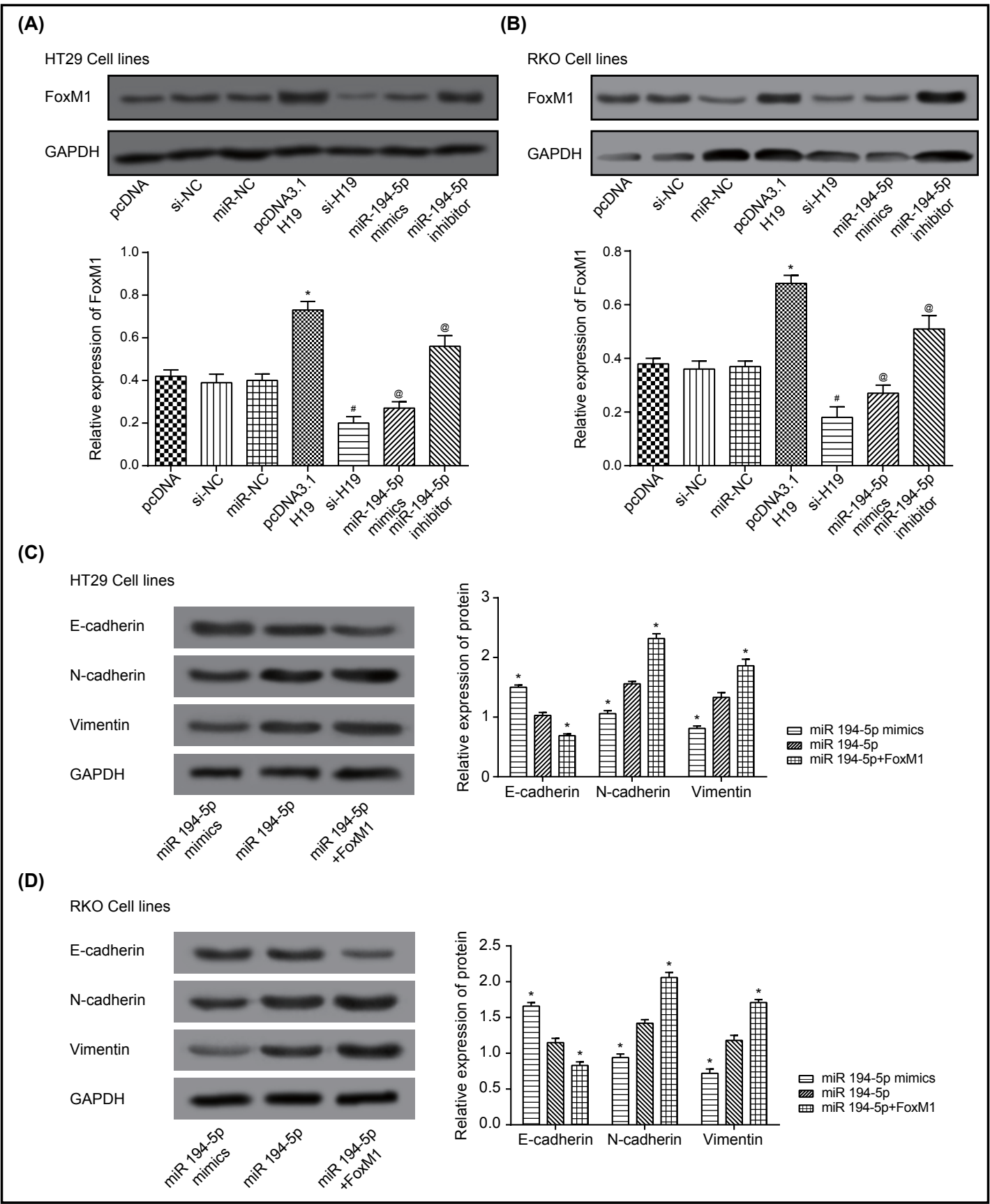

Fig. 8. The FoxM1 expressions were detected among pcDNA3.1 H19, si-H19, miR-194-5p mimics and miR-194-5p inhibitor groups within HT29 (A) and RKO (B) cell lines, and the expressions of endothelialmesenchymal transition (EMT)-related proteins (i.e. E-cadherin, N-cadherin and Vimentin) were determined among miR-194-5p, miR-194-5p mimics and miR-194-5p+FoxM1 groups within HT29 (C) and RKO (D) cell lines. A-B: *, $\mathrm{P}<0.05$ when compared with pcDNA; \#: $\mathrm{P}<0.05$ when compared with si-NC; ${ }^{\circledR}: \mathrm{P}<0.05$ when compared with miR-NC. C-D: *, P<0.05 when compared with miR-194-5p. 


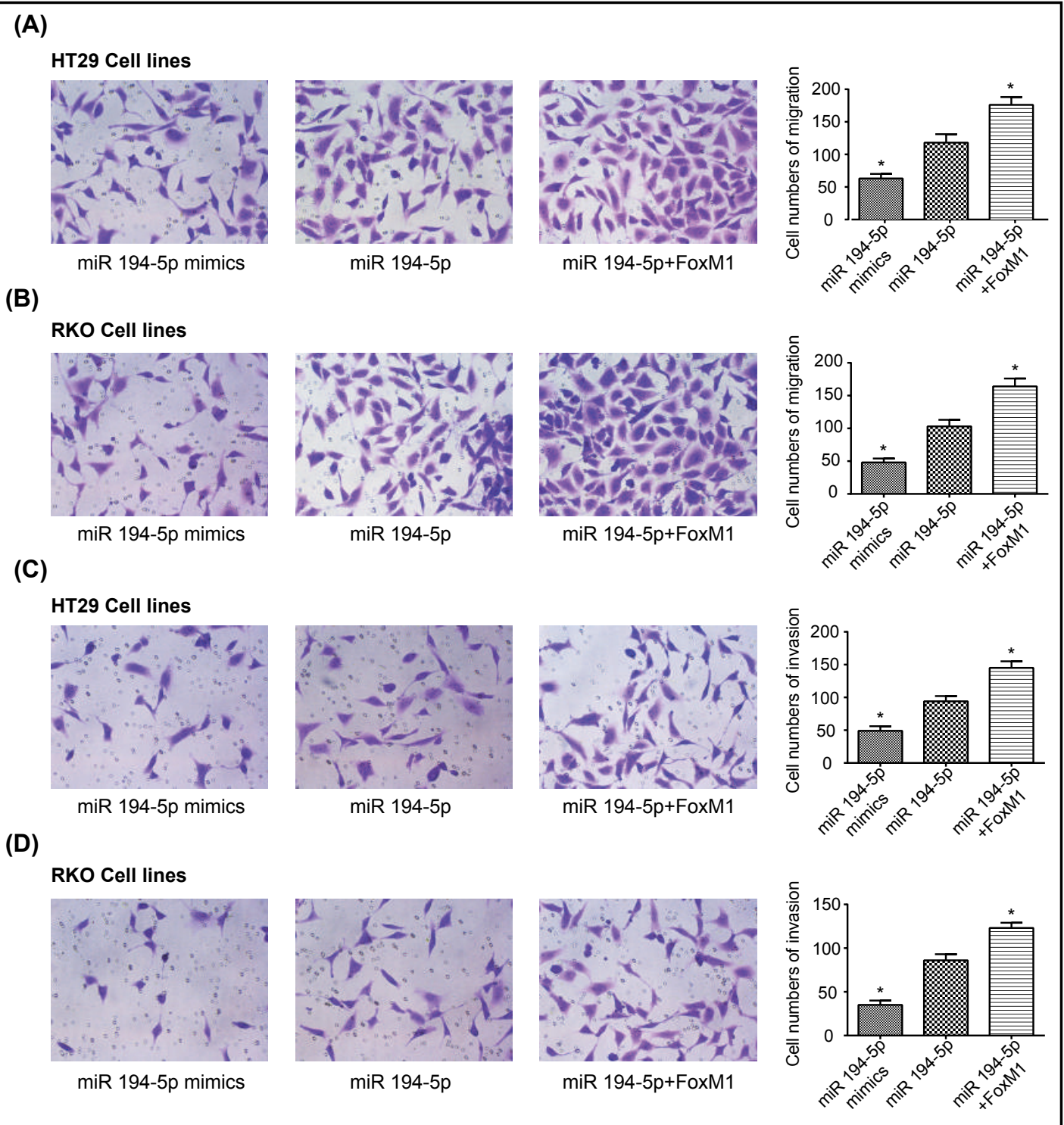

Fig. 9. The migratory (A-B) and invasive (C-D) abilities of colorectal adenocarcinoma (CRA) cells were observed by Transwell assay among miR-194-5p mimics, miR-194-5p and miR-194-5p+FoxM1 groups. *: $\mathrm{P}<0.05$ when compared with miR-194-5p. 


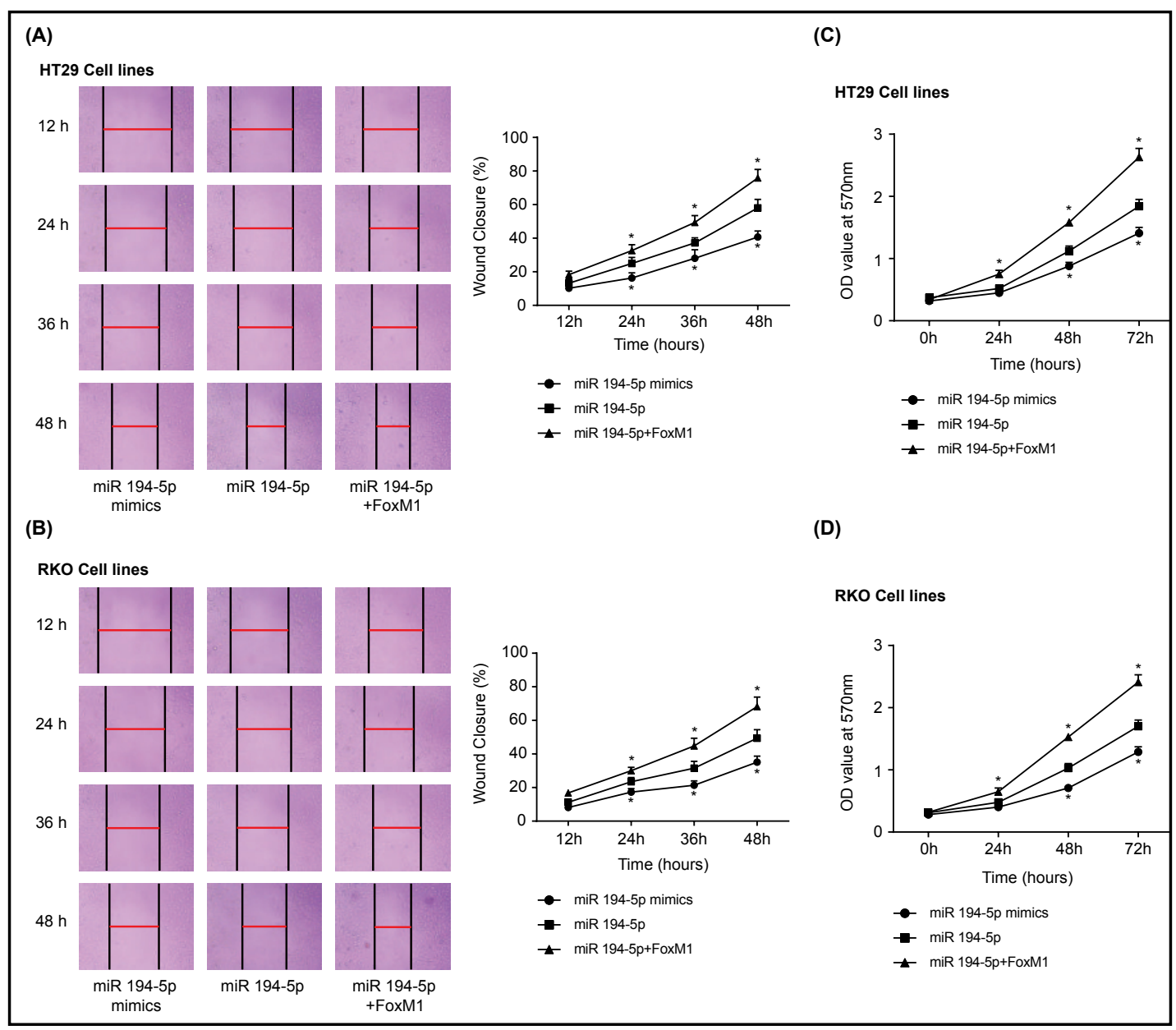

Fig. 10. The motility of HT29 and RKO cell lines were detected with scratch assay (A-B) and CCK-8 experiment (C-D) among miR-194-5p mimics, miR-194-5p and miR-194-5p+FoxM1 groups at the time points of $12 \mathrm{~h}, 24$ h, 36 h and 48 h. *: $\mathrm{P}<0.05$ when compared with miR-194-5p.

\section{Discussion}

Even though lncRNAs were initially deemed as biologically non-functional, they were later found to play a role in regulating occurrence, development, metastasis and EMT of neoplasms $[27,28]$. For instance, applying lncRNA chip to study the mammary epithelial cell MCF10A derived that about 99 types of IncRNAs might participate in the Twist-induced EMT process [29]. In addition, IncRNAs HOTAIR, MALAT-1, H19 and BANCR could accelerate tumors' metastasis through activating EMT process [30-33]. In the middle of the process, such interstitial marker proteins as $\mathrm{N}$-cadherin and vimentin were up-regulated to enhance migration and invasion of malignancies, which were originated from epithelial cells [34].

Intriguingly, the carcino-embryonic antigen gene (i.e. H19) was controversial in how it developed its cancer-promoting or cancer-suppressing function [32]. In particular, it was documented that $\mathrm{H} 19$ might motivate metastasis of pancreatic cancer cells via let-7/HMGA2 signaling [35], and H19 specifically combined with histone methyltransferase (HMT) could activate Wnt- $\beta$-catenin signaling to induce EMT of bladder cancer cells [36]. Nonetheless, Matouk et al. pointed out that there existed a positive feedback cycle between H19 and slug within hepatocellular carcinoma cells, and the two molecules jointly modified the EMT process through regulating E-cadherin expression [37]. In this investigation, we presented that H19 expression was elevated within CRA cells than within para-carcinoma tissues, and this tendency has been confirmed through in-vitro studies (Fig. 1 and 2). As for whether H19 


\section{Cellular Physiology Cell Physiol Biochem 2018;50:196-213 \begin{tabular}{l|l} 
and Biochemistry & DOI: 10.1159/000493968 \\
Published onine:3 October 2018 & $\begin{array}{l}\text { (c) } 2018 \text { The Author(s). Published by S. Karger AG, Basel } \\
\text { www.karger.com/cpb }\end{array}$
\end{tabular} \\ Li et al.: IncRNA H19/miR-194-5p/FoxM1 Signaling and Colorectal Adenocarcinoma}

cooperated with other molecules to form a feedback loop, we still have to investigate more in the future.

Based on Starbase database (http://starbase.sysu.edu.cn/pcMirLncRNAInfo. php?database=hg19\&name=hsa-miR-194-5p\&targetGene=H19\&autoId=471), H19 was manifested to directly target miR-194 within various cancers. In fact, miR-194 was aberrantly expressed within diversified malignant neoplasms [38, 39]. More specifically, miR-194 could suppress invasion of gastric cancer and liver cancer cells, and miR-194's interfering with the EMT process of tumor cells also strengthened this effect $[21,40]$. Another investigation found that miR-194 might motivate formation of colonic neoplasms by targeting AKT2, and this effect was mediated by PI3K/Akt/mTOR signaling pathway [41]. It was also deemed that miR-194 could act on MAP4K4/c-Jun/MDM2 signaling to curb CRC progression [42], and miR-194 also served as a regulatory molecule for the EMT process of CRC [25]. The consequences of this investigation testified that miR-194 was subject to the modulation of H19, and both H19 and miR-194 could synthetically encourage EMT, proliferation and viability of CRA cells (Fig. 4-6).

Interestingly, the effect exerted by miR-194 on FoxM1 was suggested to be involved in the EMT process of neoplasms [21], and several microarray assays revealed that FoxM1 was highly expressed within $>20$ solid neoplasms, including hepatocellular carcinoma, pancreatic adenocarcinoma, mastocarcinoma, ovarian cancer, lung cancer and CRC [43-47]. Besides, FoxM1 was over-expressed within actively-proliferating tumor cells, and it functioned to facilitate cell multiplication mainly by regulating cell cycle-specific genes [48]. For example, up-regulated FoxM1b expression could accelerate tumor cells' transition from G2 stage into S stage [49]. Furthermore, over-expressed FoxM1 not merely urged shaping of EMTrelated phenotypes, but also boosted expressional alterations of epithelial or mesenchymal biomarkers [50]. The serial actions have been specifically verified within hepatocellular carcinoma, pancreatic cancer and lung cancer [51-53]. Consistently, this study demonstrated that FoxM1, which was regulated by $\mathrm{H} 19$ and miR-194, acted as an oncogenic parameter for CRA (Fig. 8).

Generally speaking, the current study revealed that H19/miR-194/FoxM1 signaling pathway was essential for the development and aggravation of CRA, providing clues for developing diagnostic biomarkers and treatment targets for CRA. Nevertheless, several shortcomings should not be ignored. First of all, this investigation did not adopt animal models to verify the influences of H19, miR-194 and FoxM1 on CRA development. Secondly, additional intermediary molecules between miR-194 and FoxM1 failed to be investigated, which could more directly act on CRA pathogenesis. Finally, tissues of other ethnicities should also be investigated due to the different results arising from genetic distinction. To sum up, additional researches were recommended to remedy the above-mentioned gaps.

\section{Disclosure Statement}

The authors declare to have no competing interests.

\section{References}

1 Brenner H, Kloor M, Pox CP: Colorectal cancer. Lancet 2014;383:1490-1502.

- Li J, Yin M, Song W, Cui F, Wang W, Wang S, Zhu H: B Subunit of Human Chorionic Gonadotropin Promotes Tumor Invasion and Predicts Poor Prognosis of Early-Stage Colorectal Cancer. Cell Physiol Biochem 2018;45:237-249.

-3 Steder M, Alla V, Meier C, Spitschak A, Pahnke J, Furst K, Kowtharapu BS, Engelmann D, Petigk J, Egberts F, Schad-Trcka SG, Gross G, Nettelbeck DM, Niemetz A, Putzer BM: DNp73 exerts function in metastasis initiation by disconnecting the inhibitory role of EPLIN on IGF1R-AKT/STAT3 signaling. Cancer Cell 2013;24:512-527. 


\section{Cellular Physiology Cell Physiol Biochem 2018;50:196-213 \begin{tabular}{l|l|l|l|} 
DOI: 10.1159/000493968 2018 The Author(s). Published by S. Karger AG, Basel \\
\hline
\end{tabular} and Biochemistry

-4 Cheng F, Su L, Yao C, Liu L, Shen J, Liu C, Chen X, Luo Y, Jiang L, Shan J, Chen J, Zhu W, Shao J, Qian C: SIRT1 promotes epithelial-mesenchymal transition and metastasis in colorectal cancer by regulating Fra-1 expression. Cancer Lett 2016;375:274-283.

5 Cao H, Xu E, Liu H, Wan L, Lai M: Epithelial-mesenchymal transition in colorectal cancer metastasis: A system review. Pathol Res Pract 2015;211:557-569.

-6 Boyer B, Thiery JP: Epithelium-mesenchyme interconversion as example of epithelial plasticity. APMIS 1993;101:257-268.

7 Bai Z, Wang J, Wang T, Li Y, Zhao X, Wu G, Yang Y, Deng W, Zhang Z: The MiR-495/Annexin A3/P53 Axis Inhibits the Invasion and EMT of Colorectal Cancer Cells. Cell Physiol Biochem 2017;44:1882-1895.

-8 Li Q Li Y, Xu J, Wang S, Xu Y, Li X, Cai S: Aldolase B Overexpression is Associated with Poor Prognosis and Promotes Tumor Progression by Epithelial-Mesenchymal Transition in Colorectal Adenocarcinoma. Cell Physiol Biochem 2017;42:397-406.

-9 Ye Q, Su L, Chen D, Zheng W, Liu Y: Astragaloside IV Induced miR-134 Expression Reduces EMT and Increases Chemotherapeutic Sensitivity by Suppressing CREB1 Signaling in Colorectal Cancer Cell Line SW480. Cell Physiol Biochem 2017;43:1617-1626.

10 Del Vescovo V, Denti MA: microRNA and Lung Cancer. Adv Exp Med Biol 2015;889:153-177.

11 Li Y, Chen P, Zu L, Liu B, Wang M, Zhou Q: MicroRNA-338-3p suppresses metastasis of lung cancer cells by targeting the EMT regulator Sox4. Am J Cancer Res 2016;6:127-140.

12 Zhang W, Yuan W, Song J, Wang S, Gu X: LncRna CPS1-IT1 Suppresses Cell Proliferation, Invasion and Metastasis in Colorectal Cancer. Cell Physiol Biochem 2017;44:567-580.

13 Jiang CY, Gao Y, Wang XJ, Ruan Y, Bei XY, Wang XH, Jing YF, Zhao W, Jiang Q Li J, Han BM, Xia SJ, Zhao FJ: Long non-coding RNA lnc-MX1-1 is associated with poor clinical features and promotes cellular proliferation and invasiveness in prostate cancer. Biochem Biophys Res Commun 2016;470:721-727.

14 Brannan CI, Dees EC, Ingram RS, Tilghman SM: The product of the H19 gene may function as an RNA. Mol Cell Biol 1990;10:28-36.

15 Schwarzenbach H: Biological and Clinical Relevance of H19 in Colorectal Cancer Patients. EBioMedicine 2016;13:9-10.

-16 Allen BL, Taatjes DJ: The Mediator complex: a central integrator of transcription. Nat Rev Mol Cell Biol 2015;16:155-166.

17 Tsang WP, Ng EK, Ng SS, Jin H, Yu J, Sung JJ, Kwok TT: Oncofetal H19-derived miR-675 regulates tumor suppressor RB in human colorectal cancer. Carcinogenesis 2010;31:350-358.

18 Liu X, Jiao T, Wang Y, Su W, Tang Z, Han C: Long non-coding RNA GAS5 acts as a molecular sponge to regulate miR-23a in gastric cancer. Minerva Med 2016;9:11412-11419.

19 Liang WC, Fu WM, Wong CW, Wang Y, Wang WM, Hu GX, Zhang L, Xiao LJ, Wan DC, Zhang JF, Waye MM: The IncRNA H19 promotes epithelial to mesenchymal transition by functioning as miRNA sponges in colorectal cancer. Oncotarget 2015;6:22513-22525.

20 Wang SH, Wu XC, Zhang MD, Weng MZ, Zhou D, Quan ZW: Long noncoding RNA H19 contributes to gallbladder cancer cell proliferation by modulated miR-194-5p targeting AKT2. Tumour Biol 2016;37:9721-9730.

-21 Li Z, Ying X, Chen H, Ye P, Shen Y, Pan W, Zhang L: MicroRNA-194 inhibits the epithelial-mesenchymal transition in gastric cancer cells by targeting FoxM1. Dig Dis Sci 2014;59:2145-2152.

-22 Zhang C, Wang Y, Feng Y, Zhang Y, Ji B, Wang S, Sun Y, Zhu C, Zhang D, Sun Y: Gli1 promotes colorectal cancer metastasis in a Foxm1-dependent manner by activating EMT and PI3K-AKT signaling. Oncotarget 2016;7:86134-86147.

23 Kong FF, Qu ZQ, Yuan HH, Wang JY, Zhao M, Guo YH, Shi J, Gong XD, Zhu YL, Liu F, Zhang WY, Jiang B: Overexpression of FOXM1 is associated with EMT and is a predictor of poor prognosis in non-small cell lung cancer. Oncol Rep 2014;31:2660-2668.

24 Dong P, Kaneuchi M, Watari H, Hamada J, Sudo S, Ju J, Sakuragi N: MicroRNA-194 inhibits epithelial to mesenchymal transition of endometrial cancer cells by targeting oncogene BMI-1. Mol Cancer 2011;10:99.

25 Cai HK, Chen X, Tang YH, Deng YC: MicroRNA-194 modulates epithelial-mesenchymal transition in human colorectal cancer metastasis. Onco Targets Ther 2017;10:1269-1278.

-26 Ahmed D, Eide PW, Eilertsen IA, Danielsen SA, Eknaes M, Hektoen M, Lind GE, Lothe RA: Epigenetic and genetic features of 24 colon cancer cell lines. Oncogenesis 2013;2:e71. 


\section{Cellular Physiology Cell Physiol Biochem 2018;50:196-213 \begin{tabular}{l|l|l|}
\hline DOI: 10.1159/000493968 2018 & $\begin{array}{l}\text { C) 2018 The Author(s). Published by S. Karger AG, Basel } \\
\text { www.karger.com/cpb }\end{array}$ \\
\hline
\end{tabular}

27 Kung JT, Colognori D, Lee JT: Long noncoding RNAs: past, present, and future. Genetics 2013;193:651-669.

28 Gibb EA, Brown CJ, Lam WL: The functional role of long non-coding RNA in human carcinomas. Mol Cancer 2011;10:38.

-29 Hu P, Yang J, Hou Y, Zhang H, Zeng Z, Zhao L, Yu T, Tang X, Tu G, Cui X, Liu M: LncRNA expression signatures of twist-induced epithelial-to-mesenchymal transition in MCF10A cells. Cell Signal 2014;26:83-93.

-30 Xu ZY, Yu QM, Du YA, Yang LT, Dong RZ, Huang L, Yu PF, Cheng XD: Knockdown of long non-coding RNA HOTAIR suppresses tumor invasion and reverses epithelial-mesenchymal transition in gastric cancer. Int J Biol Sci 2013;9:587-597.

-31 Gutschner T, Hammerle M, Diederichs S: MALAT1 -- a paradigm for long noncoding RNA function in cancer. J Mol Med (Berl) 2013;91:791-801.

-32 Matouk IJ, Mezan S, Mizrahi A, Ohana P, Abu-Lail R, Fellig Y, Degroot N, Galun E, Hochberg A: The oncofetal H19 RNA connection: hypoxia, p53 and cancer. Biochim Biophys Acta 2010;1803:443-451.

-33 Flockhart RJ, Dan EW, Qu K, Mascarenhas N, Kovalski J, Kretz M, Paul KA: Abstract LB-248: BRAFV600E remodels the melanocyte transcriptome and induces BANCR to regulate melanoma cell migration. Genome Research 2012;22:1006.

34 Kraljevic Pavelic S, Sedic M, Bosnjak H, Spaventi S, Pavelic K: Metastasis: new perspectives on an old problem. Mol Cancer 2011;10:22.

35 Ma C, Nong K, Zhu H, Wang W, Huang X, Yuan Z, Ai K: H19 promotes pancreatic cancer metastasis by derepressing let-7's suppression on its target HMGA2-mediated EMT. Tumour Biol 2014;35:9163-9169.

-36 Luo M, Li Z, Wang W, Zeng Y, Liu Z, Qiu J: Long non-coding RNA H19 increases bladder cancer metastasis by associating with EZH2 and inhibiting E-cadherin expression. Cancer Lett 2013;333:213-221.

-37 Matouk IJ, Raveh E, Abu-lail R, Mezan S, Gilon M, Gershtain E, Birman T, Gallula J, Schneider T, Barkali M, Richler C, Fellig Y, Sorin V, Hubert A, Hochberg A, Czerniak A: Oncofetal H19 RNA promotes tumor metastasis. Biochim Biophys Acta 2014;1843:1414-1426.

-38 Senanayake U, Das S, Vesely P, Alzoughbi W, Frohlich LF, Chowdhury P, Leuschner I, Hoefler G, Guertl B: miR-192, miR-194, miR-215, miR-200c and miR-141 are downregulated and their common target ACVR2B is strongly expressed in renal childhood neoplasms. Carcinogenesis 2012;33:1014-1021.

-39 Saad R, Chen Z, Zhu S, Jia P, Zhao Z, Washington MK, Belkhiri A, El-Rifai W: Deciphering the unique microRNA signature in human esophageal adenocarcinoma. PLoS One 2013;8:e64463.

40 Meng Z, Fu X, Chen X, Zeng S, Tian Y, Jove R, Xu R, Huang W: miR-194 is a marker of hepatic epithelial cells and suppresses metastasis of liver cancer cells in mice. Hepatology 2010;52:2148-2157.

41 Zhao HJ, Ren LL, Wang ZH, Sun TT, Yu YN, Wang YC, Yan TT, Zou W, He J, Zhang Y, Hong J, Fang JY: MiR194 deregulation contributes to colorectal carcinogenesis via targeting AKT2 pathway. Theranostics 2014;4:1193-1208.

42 Wang B, Shen ZL, Gao ZD, Zhao G, Wang CY, Yang Y, Zhang JZ, Yan YC, Shen C, Jiang KW, Ye YJ, Wang S: MiR194, commonly repressed in colorectal cancer, suppresses tumor growth by regulating the MAP4K4/c-Jun/ MDM2 signaling pathway. Cell Cycle 2015;14:1046-1058.

43 Pilarsky C, Wenzig M, Specht T, Saeger HD, Grutzmann R: Identification and validation of commonly overexpressed genes in solid tumors by comparison of microarray data. Neoplasia 2004;6:744-750.

-44 Kim IM, Ackerson T, Ramakrishna S, Tretiakova M, Wang IC, Kalin TV, Major ML, Gusarova GA, Yoder HM, Costa RH, Kalinichenko VV: The Forkhead Box m1 transcription factor stimulates the proliferation of tumor cells during development of lung cancer. Cancer Res 2006;66:2153-2161.

45 Wang Z, Ahmad A, Banerjee S, Azmi A, Kong D, Li Y, Sarkar FH: FoxM1 is a novel target of a natural agent in pancreatic cancer. Pharm Res 2010;27:1159-1168.

-46 Uddin S, Ahmed M, Hussain A, Abubaker J, Al-Sanea N, AbdulJabbar A, Ashari LH, Alhomoud S, Al-Dayel F, Jehan Z, Bavi P, Siraj AK, Al-Kuraya KS: Genome-wide expression analysis of Middle Eastern colorectal cancer reveals FOXM1 as a novel target for cancer therapy. Am J Pathol 2011;178:537-547.

47 Wen N, Wang Y, Wen L, Zhao SH, Ai ZH, Wang Y, Wu B, Lu HX, Yang H, Liu WC, Li Y: Overexpression of FOXM1 predicts poor prognosis and promotes cancer cell proliferation, migration and invasion in epithelial ovarian cancer. J Transl Med 2014;12:134.

-48 Wierstra I, Alves J: FOXM1, a typical proliferation-associated transcription factor. Biol Chem 2007;388:1257-1274. 


\section{Cellular Physiology Cell Physiol Biochem 2018;50:196-213

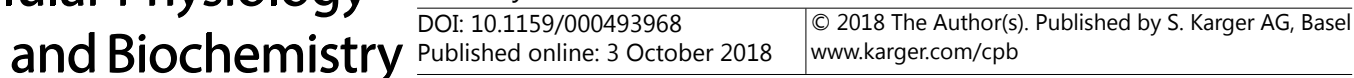

49 Wang X, Kiyokawa H, Dennewitz MB, Costa RH: The Forkhead Box m1b transcription factor is essential for hepatocyte DNA replication and mitosis during mouse liver regeneration. Proc Natl Acad Sci U S A 2002;99:16881-16886.

50 Bao B, Wang Z, Ali S, Kong D, Banerjee S, Ahmad A, Li Y, Azmi AS, Miele L, Sarkar FH: Over-expression of FoxM1 leads to epithelial-mesenchymal transition and cancer stem cell phenotype in pancreatic cancer cells. J Cell Biochem 2011;112:2296-2306.

-51 Park HJ, Gusarova G, Wang Z, Carr JR, Li J, Kim KH, Qiu J, Park YD, Williamson PR, Hay N, Tyner AL, Lau LF, Costa RH, Raychaudhuri P: Deregulation of FoxM1b leads to tumour metastasis. EMBO Mol Med 2011;3:2134.

52 Huang C, Qiu Z, Wang L, Peng Z, Jia Z, Logsdon CD, Le X, Wei D, Huang S, Xie K: A novel FoxM1-caveolin signaling pathway promotes pancreatic cancer invasion and metastasis. Cancer Res 2012;72:655-665.

53 Wei P, Zhang N, Wang Y, Li D, Wang L, Sun X, Shen C, Yang Y, Zhou X, Du X: FOXM1 promotes lung adenocarcinoma invasion and metastasis by upregulating SNAIL. Int J Biol Sci 2015;11:186-198. 